\title{
Performance of Wheat in Relation to Sowing Dates and Nitrogen Levels under Rainfed Conditions of Kashmir
}

\author{
Shahid B. Dar ${ }^{1 *}$, R.H. Kanth ${ }^{1}$, Waseem Raja ${ }^{1}$, S.A. Bangroo ${ }^{2}$ and S.A. Mir ${ }^{3}$ \\ ${ }^{1}$ Division of Agronomy, Sher-e-Kashmir University of Agricultural Sciences and Technology \\ of Kashmir, FOA, Wadura, Jammu and Kashmir-193201, India \\ ${ }^{2}$ Division of Soil Science, ${ }^{3}$ Division of Agricultural Statistics, Sher-e-Kashmir University of \\ Agricultural Sciences and Technology of Kashmir, FOH, Shalimar, \\ Jammu and Kashmir-190006, India \\ *Corresponding author
}

\section{A B S T R A C T}

\begin{abstract}
A field experiment was carried out at experimental farm, faculty of agriculture, Wadura, SKUAST-Kashmir (J\&K) during Rabi 2015-16 to study the effect of sowing dates and nitrogen levels under rainfed conditions of Kashmir. Experiment was conducted in split plot design, keeping three sowing dates $\left(\mathrm{D}_{1}-15^{\text {th }}\right.$ October, $\mathrm{D}_{2}-30^{\text {th }}$ October and $\mathrm{D}_{3}-15^{\text {th }}$ November) in main plots and four nitrogen levels $\left(\mathrm{N}_{0}-0 \mathrm{~kg} \mathrm{~N} \mathrm{ha}^{-1}, \mathrm{~N}_{1}-50 \mathrm{~N} \mathrm{ha}^{-1}, \mathrm{~N}_{2}-100 \mathrm{~N}\right.$ $\mathrm{ha}^{-1}$ and $\mathrm{N}_{3}-150 \mathrm{~N} \mathrm{ha}^{-1}$ ) and was replicated four times. The results revealed that grain yield decreased by $10.6 \%$ from $D_{1}$ to $D_{2}, 7.6 \%$ from $D_{2}$ to $D_{3}$ and 17.4 from $D_{1}$ to $D_{3}$. Growth characters like plant height $(94.94 \mathrm{~cm})$, dry matter accumulation $\left(110.7 \mathrm{q} \mathrm{ha}^{-1}\right)$, tillers $\mathrm{m}^{-2}$ (311.5), leaf area index (3.60) and yield attributes like effective tillers (275.93), grains spike $^{-1}(40.14)$ and test weight $(2.52 \mathrm{~g})$ were recorded highest with $15^{\text {th }}$ October sowing. Increasing $\mathrm{N}$ levels results in increase in growth characters, yield attributes and yield and highest valves were recorded with application of $150 \mathrm{~kg} \mathrm{~N} \mathrm{ha}^{-1}\left(\mathrm{~N}_{3}\right)$ however, remained statistically at par with $100 \mathrm{~kg} \mathrm{~N} \mathrm{ha}^{-1}\left(\mathrm{~N}_{2}\right)$. The study finally concluded that delay in sowing reduces the grain yield, while as irrespective of sowing dates, application of 100 $\mathrm{Kg} \mathrm{N} \mathrm{ha}{ }^{-1}$ to crop resulted in higher growth, yield attributes and yield of wheat as compared to other nitrogen levels, further increase in $\mathrm{N}$ application beyond $100 \mathrm{Kg} \mathrm{N} \mathrm{ha}{ }^{-1}$ showed non-significant increase.
\end{abstract}

Keywords

Nitrogen, Sowing dates, Wheat, Rainfed and yield

Article Info

Accepted: 20 March 2018 Available Online: 10 April 2018

\section{Introduction}

Wheat (Triticum aestivum L.) is the world's most widely cultivated food crop. It is eaten in various forms by more than one thousand million human beings in the world (Iftikhar et al., 2002). Besides staple food for human beings, wheat straw also serves as good source of feed for animals (Sarwar et al., 2006). In India, wheat production was recorded as 95.91 million tonnes (mt) from an area of $30 \mathrm{~m}$ ha in 2013-14 (GoI, 2016). It supplies 21 per cent of the per capita food energy and 18 per cent of dietary protein in the country (Balasubramanian et al., 2012). The three important wheat growing states (Uttar 
Pradesh, Punjab and Haryana) account for about $80 \%$ of the total wheat production in the country. In Jammu and Kashmir wheat growing areas remained confined to Jammu region and in valley besides having lot of potential area under wheat cultivation is relatively very low (Kour et al., 2012).

There are many factors responsible but appropriate dates of sowing and proper nitrogen $(\mathrm{N})$ fertilization are important factors for sustainable production of wheat under temperate conditions of Kashmir. Precipitation is a critical factor for various geomorphological, hydrological, ecological and agricultural processes, especially in drier regions (Sepaskhah et al., 2006). Crop production in dryland regions is mainly determined by precipitation and is extremely vulnerable to changes in precipitation patterns and amounts. In such water-limited environments soil water content at sowing is important in determining wheat germination, emergence and plant establishment. Thus the choice of sowing date is an important management option to optimize grain yield. The appropriate selection of a planting date can have a dramatic impact on both the quantity and quality of crop yield (Gul et al., 2008). Numerous studies (Bassu et al., 2009; Bannayan et al., 2013) have revealed yield advantage with early sowing and yield reduction under delayed sowing after the ideal time (Qasim et al., 2008). Adjusting the planting date can avoid the exposure of wheat crop to adverse environmental conditions. Nitrogen constitutes an integral part of improved crop production technology. Supply of adequate amounts of nitrogen and its management is one of the most important factors influencing the yield of not only wheat but other crops as well. Good management of nitrogen fertilization of wheat crop is important to obtain higher yields and profit. $\mathrm{N}$ fertilization practices can provide a sufficient $\mathrm{N}$ supply for plants to achieve the potential yield allowed by the actual climatic conditions (Lemaire et al., 2008). Technological quality of grain depends mainly on grain protein content that is influenced by crop nitrogen fertilisation, both by the application time and by the amount of nitrogen (Daniel and Triboi 2000). It is also important, from economic point of view to reduce the cost of cultivation and at the same time, to avoid the access nitrogen fertilization to reduce the risk of leaching losses (Rinaldi, 2004). So, it is essential to apply $\mathrm{N}$ fertilizers on adequate time and rate. The economically optimum rate of $\mathrm{N}$ fertilizer for crops may vary spatially due to variation in soil characteristics and temporally due to the interactions of environmental factors (Mamo et al., 2003; Subedi and $\mathrm{Ma}$, 2007). Under rainfed agriculture, lack of water in the root zone can make the applied $\mathrm{N}$ unavailable to plant and subject to leaching and runoff later. Therefore, there is a need for a more demand-based application of $\mathrm{N}$ fertilizer depending on the absorption capacity of the soil and plant under the prevailing climatic and soil physicchemical conditions. In view of this, an experiment was carried out to o study the effect of sowing dates and nitrogen levels under rainfed conditions of Kashmir.

\section{Materials and Methods}

Field experiment was conducted during Rabi 2015-16 season with different sowing dates and nitrogen levels at Research Farm of Faculty of Agriculture, SKUAST-K, Wadura Sopore $\left(34^{0} 20 \mathrm{~N}\right.$ and $74^{0} 24 \mathrm{E}$ at an altitude of $1588 \mathrm{~m}$ above mean sea level). The experimental soil was well drained silty clay loam in texture with $\mathrm{pH} 7.6$ (Jackson, 1973), high in inorganic C $0.86 \%$ (Walkley and Black 1934), medium in available N $315.4 \mathrm{~kg}$ $\mathrm{ha}^{-1}$ (Subbiah and Asija, 1954), available P $21.5 \mathrm{~kg} \mathrm{ha}^{-1}$ (Olsen et al., 1954) and available $\mathrm{K} 248.7 \mathrm{~kg} \mathrm{ha}^{-1}$ (Jackson, 1953). The climate of the experimental site is temperate 
characterized by moderately hot summers and very cold winters. Under average climatic conditions, the area receives $690 \mathrm{~mm}$ of mean annual rainfall most of which occurs from December to April. Rainfall received during the growing season (October to June) was $620.6 \mathrm{~mm}$. The mean weekly maximum and minimum temperatures during the growing seasons varied from 17.50 to $3.79{ }^{\circ} \mathrm{C}$. The experiment consisting of twelve treatments (Table 1) and was conducted in split plot design, keeping three sowing dates $\left(D_{1}-15^{\text {th }}\right.$ October, $\mathrm{D}_{2}-30^{\text {th }}$ October and $\mathrm{D}_{3}-15^{\text {th }}$ November) in main plots and four nitrogen levels $\left(\mathrm{N}_{0}-0 \mathrm{~kg} \mathrm{~N}^{-1}, \mathrm{~N}_{1}-50 \mathrm{~N}^{-1}, \mathrm{~N}_{2}-100 \mathrm{~N}\right.$ $\mathrm{ha}^{-1}$ and $\mathrm{N}_{3}-150 \mathrm{~N} \mathrm{ha}^{-1}$ ) and was replicated four times. The sowing of the crop and nitrogen was applied as per treatments. Wheat (SW-2) was sown @ $100 \mathrm{~kg} / \mathrm{ha}$ at $23 \times 10 \mathrm{~cm}$ spacing. All other agronomic practices were followed as per standard recommendations. The grain and straw yield of wheat were recorded and observation on growth and yield attributers were recorded from five randomly selected tagged plants from each plot Data on yield attributes and yield were collected at harvesting. Nutrient uptake was calculated by multiplying grain and straw yield by nutrient content. The data were analyzed as per the standard procedure for Analysis of Variance by SAS, version 9.4. The significance of treatments was tested by ' $F$ ' test (Variance ratio). The difference in the treatment mean was tested by using critical difference (CD) at $5 \%$ level of probability.

\section{Growth Attributes}

Results revealed that the various growth parameters (Table 2) decreased significantly with each delay in sowing date. Early sowing date $\left(15^{\text {th }}\right.$ October $)$ recorded significantly taller plants $(94.99 \mathrm{~cm})$, dry matter accumulation (78.21 $\mathrm{q} \mathrm{ha}^{-1}$ ), total tillers (269.3) and leaf area index (2.72). Growth attributes decreased with deferral in sowing time because of less favourable weather conditions and shorter crop growing period that resulted in net photosynthesis as compared to optimum sowing dates. Several authors have reported reduction in growth attributes with delay in sowing time from the optimum (Jat et al., 2013; Tomar et al., 2014 and Mumtaz et al., 2015). During the later stages plant height, total tillers and dry matter accumulation in $D_{2}$ and $D_{3}$ was statistically at par with each other. Late sown crop was subjected to low temperature during early growth period, the longer vegetative phase led to production of growth attributes. Similar findings were also recorded by Ghadekar et al., (1992). DMA decreased with deferral in sowing time because of less favourable weather conditions and shorter crop growing period, reduced plant height and LAI. Alam et al., 2013; Kumar et al., 2013 and Deshmukh et al., 2015 also reported that DMA was higher in early sown crop because of favourable cool climate accessible for longer period as compared to late sown crop. Further, since this period coincide with conducive period for crop growth reducing death of tiller and senescence of leaf, thus accumulating more dry matter

Increasing the nitrogen fertilization increase growth attributes as compared to growth attributes recorded in control $\left(\mathrm{N}_{1}\right)$. Application of $150 \mathrm{~kg} \mathrm{ha}^{-1}\left(\mathrm{~N}_{3}\right)$ recorded highest plant height $(95.30 \mathrm{~cm})$, total tillers $(306.5)$, leaf area index (3.91) and total dry matter accumulation (116.59 $\mathrm{q} \mathrm{ha}^{-1}$ ) but remained statistically at par with the treatment involving application of $100 \mathrm{~kg} \mathrm{~N}^{-1}\left(\mathrm{~N}_{2}\right)$ and were significantly superior over control $\left(\mathrm{N}_{1}\right)$ and $\mathrm{N}_{2}$ (50 kg N ha ${ }^{-1}$ ). While as the minimum plant height $(83.25 \mathrm{~cm})$, total tillers $(269.4)$, leaf area index (2.72) and total dry matter accumulation (78.21 $\mathrm{q} \mathrm{ha}^{-1}$ ) were recorded in control. Similar findings were also reported by Shahid and Ram (2017). This increase in growth attributes might have been due to more 
and quick supply of $\mathrm{N}$ with heavy application of nitrogen fertilization which increased photosynthetic activity, cell division, elongation and differentiation etc. resulting in higher growth attributes.

\section{Yield and yield attributes}

The data depicted in Table 3 revealed significantly higher yield attributes viz. total tillers (362.18), effective tillers (275.93), grains/spike (40.41) and spike weight (2.52 g) were recorded with 15 October sowing. With each delay in sowing there was a significant reduction in the yield attributes. The minimum yield attributes viz. total tillers (323.93), effective tillers (251.58), grains spike ${ }^{-1}(37.86)$ and spike weight $(2.54 \mathrm{~g})$ were recorded in $15^{\text {th }}$ November sowing. The total and effective tillers were higher in earlier sowing due to higher number of total tillers at all the growth stages together with favourable weather conditions throughout the growing season. Ramesh et al., (2005) also reported reduction in number of total and effective tillers with deferral in sowing time. Significantly higher grains spike ${ }^{-1}$ and spike weight with $\mathrm{D}_{1}$ as compared to all other sowing dates may be attributed to unfavourable effect of late sowing on yield attributing characters like grains spike ${ }^{-1}$ and spike weight can be attributed to sharp rise in temperature accompanied by hot winds adversely affecting the grain development and resulted in immature and shriveled grains in the late sown crop, which was in the milk stage during that period. $15^{\text {th }}$ October sown crop, however, was at advantage because after having completed its vegetative growth satisfactorily, it entered reproductive phase when grain development and maturity was subjected to steady rise in temperature. Similar findings were confirmed by Angadi and Janawade (2001) and Singh and Pal (2003).

Table.1 Treatment combination details

\begin{tabular}{|l|l|l|l|}
\hline Mean factor & Sub factor & Treatment combination & Combination details \\
\hline $\mathrm{D}_{1}$ & $\mathrm{~N}_{0}$ & $\mathrm{D}_{1} \mathrm{~N}_{0}$ & 15 October with $0 \mathrm{~kg} \mathrm{ha}^{-1}$ \\
\hline & $\mathrm{N}_{1}$ & $\mathrm{D}_{1} \mathrm{~N}_{1}$ & 15 October with $50 \mathrm{~kg} \mathrm{ha}^{-1}$ \\
\hline $\mathrm{N}_{2}$ & $\mathrm{D}_{1} \mathrm{~N}_{2}$ & 15 October with $100 \mathrm{~kg} \mathrm{ha}^{-1}$ \\
\hline $\mathrm{N}_{3}$ & $\mathrm{D}_{1} \mathrm{~N}_{3}$ & 15 October with $150 \mathrm{~kg} \mathrm{ha}^{-1}$ \\
\hline $\mathrm{N}_{0}$ & $\mathrm{D}_{2} \mathrm{~N}_{0}$ & 30 October with $0 \mathrm{~kg} \mathrm{ha}^{-1}$ \\
\hline & $\mathrm{N}_{1}$ & $\mathrm{D}_{2} \mathrm{~N}_{1}$ & 30 October with $50 \mathrm{~kg} \mathrm{ha}^{-1}$ \\
\hline & $\mathrm{N}_{2}$ & $\mathrm{D}_{2} \mathrm{~N}_{2}$ & 30 October with $100 \mathrm{~kg} \mathrm{ha}^{-1}$ \\
\hline & $\mathrm{N}_{3}$ & $\mathrm{D}_{2} \mathrm{~N}_{3}$ & 30 October with $150 \mathrm{~kg} \mathrm{ha}^{-1}$ \\
\hline $\mathrm{D}_{3}$ & $\mathrm{D}_{3} \mathrm{~N}_{0}$ & 15 November with $0 \mathrm{~kg} \mathrm{ha}^{-1}$ \\
\hline & $\mathrm{N}_{1}$ & $\mathrm{D}_{3} \mathrm{~N}_{1}$ & 15 November with $50 \mathrm{~kg} \mathrm{ha}^{-1}$ \\
\hline & $\mathrm{N}_{2}$ & $\mathrm{D}_{3} \mathrm{~N}_{2}$ & 15 November with $100 \mathrm{~kg} \mathrm{ha}^{-1}$ \\
\hline & $\mathrm{N}_{3}$ & $\mathrm{D}_{3} \mathrm{~N}_{3}$ & 15 November with $150 \mathrm{~kg} \mathrm{ha}^{-1}$ \\
\hline
\end{tabular}


Table. 2 Growth attributes of wheat as influenced by sowing dates and nitrogen levels

\begin{tabular}{|c|c|c|c|c|}
\hline \multirow[t]{2}{*}{ Treatments } & \multicolumn{4}{|c|}{ Growth attributes } \\
\hline & $\begin{array}{l}\text { Plant height } \\
\text { (cm) }\end{array}$ & $\begin{array}{c}\text { Dry matter accumulation } \\
\qquad\left(\mathbf{q ~ h a} \mathbf{~}^{-1}\right)\end{array}$ & Leaf Area Index & Tillers $\left(\mathbf{m}^{-2}\right)$ \\
\hline \multicolumn{5}{|l|}{ Sowing dates } \\
\hline$D_{1}$ & 94.94 & 110.70 & 3.60 & 323.49 \\
\hline$D_{2}$ & 90.15 & 99.54 & 3.53 & 304.51 \\
\hline$D_{3}$ & 88.71 & 92.46 & 3.42 & 288.62 \\
\hline $\mathrm{CD}(\mathrm{P}=0.05$ & 3.68 & 3.39 & 0.055 & 9.44 \\
\hline \multicolumn{5}{|c|}{ Nitrogen levels } \\
\hline $\mathbf{N}_{0}$ & 83.25 & 78.21 & 2.72 & 281.44 \\
\hline$N_{1}$ & 90.46 & 97.64 & 3.53 & 306.25 \\
\hline $\mathbf{N}_{2}$ & 95.30 & 111.17 & 3.91 & 316.02 \\
\hline $\mathbf{N}_{3}$ & 95.30 & 116.59 & 3.91 & 318.45 \\
\hline $\mathrm{CD}(\mathrm{p}=0.05)$ & 3.15 & 4.26 & 0.055 & 7.90 \\
\hline
\end{tabular}

Table.3 Yield attributes of wheat as influenced by sowing dates and nitrogen levels

\begin{tabular}{|c|c|c|c|c|}
\hline \multirow[t]{2}{*}{ Treatments } & \multicolumn{4}{|c|}{ Yield attributes } \\
\hline & Total Tillers $\left(\mathrm{m}^{-2}\right)$ & Effective tillers $\left(\mathrm{m}^{-2}\right)$ & Grains Spike ${ }^{-1}$ & Spike weight (g) \\
\hline \multicolumn{5}{|l|}{ Sowing dates } \\
\hline$D_{1}$ & 312.18 & 275.93 & 40.14 & 2.52 \\
\hline $\mathbf{D}_{2}$ & 297.07 & 262.46 & 39.18 & 2.50 \\
\hline$D_{3}$ & 283.93 & 251.58 & 37.86 & 2.45 \\
\hline $\mathrm{CD}(\mathrm{P}=\mathbf{0 . 0 5}$ & 11.43 & 9.05 & 1.13 & 0.01 \\
\hline \multicolumn{5}{|c|}{ Nitrogen levels } \\
\hline $\mathbf{N}_{0}$ & 277.52 & 225.33 & 36.75 & 37.11 \\
\hline $\mathrm{N}_{1}$ & 294.83 & 267.50 & 38.20 & 38.57 \\
\hline $\mathbf{N}_{2}$ & 306.35 & 279.02 & 40.69 & 41.02 \\
\hline $\mathbf{N}_{3}$ & 312.20 & 81.45 & 40.60 & 0.86 \\
\hline $\mathrm{CD}(\mathrm{p}=0.05)$ & 8.16 & 6.79 & 0.8 & 1.15 \\
\hline
\end{tabular}

Table.4 Grain yield $\left(\mathrm{q} \mathrm{ha}{ }^{-1}\right)$, Straw yield $\left(\mathrm{q} \mathrm{ha}^{-1}\right)$, Biological yield $\left(\mathrm{q} \mathrm{ha}^{-1}\right)$ and Harvest index $(\%)$, of wheat as influenced by different sowing dates and nitrogen levels

\begin{tabular}{|c|c|c|c|c|c|c|}
\hline Treatments & $\begin{array}{l}\text { Grain Yield } \\
\qquad\left(\mathbf{q} \mathbf{h a}^{-1}\right)\end{array}$ & $\begin{array}{l}\text { Straw Yield } \\
\qquad\left(\mathbf{q} \mathbf{h a}^{-1}\right)\end{array}$ & $\begin{array}{c}\text { Biological } \\
\text { Yield }\left(\mathbf{q} \mathbf{h a}^{-1}\right)\end{array}$ & $\begin{array}{l}\text { Harvest Index } \\
(\%)\end{array}$ & $\begin{array}{c}\text { Protein } \\
\text { content } \\
(\%)\end{array}$ & $\begin{array}{c}\text { Gluten content } \\
(\%)\end{array}$ \\
\hline \multicolumn{7}{|l|}{ Sowing dates } \\
\hline$D_{1}$ & 44.09 & 81.52 & 125.61 & 34.98 & 9.62 & 8.95 \\
\hline $\mathrm{D}_{2}$ & 39.41 & 75.75 & 115.17 & 34.28 & 10.23 & 9.30 \\
\hline$D_{3}$ & 36.40 & 71.52 & 107.93 & 33.73 & 10.34 & 9.38 \\
\hline $\mathrm{CD}(\mathrm{P}=0.05$ & 2.4 & 3.57 & 4.81 & NS & 0.546 & 0.18 \\
\hline \multicolumn{7}{|l|}{ Nitrogen levels } \\
\hline $\mathbf{N}_{0}$ & 31.00 & 61.67 & 92.67 & 33.44 & 9.45 & 8.74 \\
\hline $\mathrm{N}_{1}$ & 40.09 & 72.55 & 112.64 & 35.37 & 10.07 & 9.18 \\
\hline $\mathbf{N}_{2}$ & 44.04 & 84.01 & 128.05 & 34.34 & 10.35 & 9.44 \\
\hline $\mathbf{N}_{3}$ & 44.75 & 86.83 & 131.59 & 33.96 & 10.38 & 9.48 \\
\hline $\mathrm{CD}(\mathrm{p}=0.05)$ & 2.06 & 3.26 & 4.22 & NS & 0.27 & 0.29 \\
\hline
\end{tabular}


Table.5 Grain yield $\left(\mathrm{q} \mathrm{ha}^{-1}\right)$ as influenced by interaction between sowing dates and nitrogen levels

\begin{tabular}{|l|c|c|c|c|c|}
\hline $\begin{array}{l}\text { Sowing } \\
\text { date }\end{array}$ & 0 & 50 & 100 & 150 & Mean \\
\hline $\mathbf{D}_{1}$ & 32.87 & 44.05 & 49.42 & 50.02 & 44.09 \\
\hline $\mathbf{D}_{2}$ & 31.40 & 39.22 & 43.25 & 43.80 & 39.41 \\
\hline $\mathbf{D}_{3}$ & 28.72 & 37.00 & 39.45 & 40.45 & 36.40 \\
\hline Mean & 31.00 & 40.09 & 44.04 & 44.75 & \\
\hline LSD & & $\begin{array}{c}\text { Sowing } \\
\text { date }=2.40\end{array}$ & $\begin{array}{c}\text { Nitrogen } \\
\text { levels }=2.06\end{array}$ & Interaction=NS & \\
\hline & & Sem $\pm=0.68$ & Sem $\pm=0.70$ & Sem $\pm=1.36$ & \\
\hline
\end{tabular}

On the other hand, application of $150 \mathrm{~kg} \mathrm{ha}^{-1}$ $\left(\mathrm{N}_{3}\right)$ recorded total tillers (355.53), effective tillers (281.45), grains/spike (40.60) and spike weight $(2.53 \mathrm{~g})$ and remained statistically at par with the treatment involving application of $100 \mathrm{~kg} \mathrm{~N} \mathrm{ha}^{-1}\left(\mathrm{~N}_{2}\right)$ and were significantly superior over control $\left(\mathrm{N}_{1}\right)$ and $\mathrm{N}_{2}(50 \mathrm{~kg} \mathrm{~N}$ $\left.\mathrm{ha}^{-1}\right)$. While as the minimum total tillers (320.85), effective tillers (255.33), grains spike $^{-1}$ (36.75) and spike weight (2.53 g) were recorded in control. The reduction in number of tillers with increase in nitrogen deficit can be attributed to less availability of nitrogen for tiller development. The decrease in number of tillers with increase in nitrogen deficit has also been reported by Ramessh et al., (2005) and Kour et al., (2012). The reduction in 1000 grain weight in deficit nitrogen treatments may have been due to shrivelling of grains. Reduction in 1000 grain weight with increase in nitrogen deficit has also been quoted by Kour et al., (2012).

Date of sowing and nitrogen levels had significant bearing on yield of wheat (Table 4). The grain yield, straw yield and biological yield was significantly higher in $D_{1}$ as compared to all other sowing dates.

The highest grain yield of $44.09 \mathrm{q} \mathrm{ha}^{-1}$, straw yield $\left(81.50 \mathrm{q} \mathrm{ha}^{-1}\right)$ and biological yield (125.61 q ha $\left.{ }^{-1}\right)$ was obtained when sowing was done on $15^{\text {th }}$ October which was significantly higher than $\mathrm{D}_{2}$ and $\mathrm{D}_{3}$ The grain yield, straw yield and biological yield decreased by $17.44,9.5$ and $14.07 \%$ from $\mathrm{D}_{1}$ to $\mathrm{D}_{3}$, respectively. The decline in grain yield with delay in sowing may be due to shortening of the duration of each developmental phase and forced maturity of late sown wheat, reduction in plant height, DMA, LAI and tiller density. Moreover, the yield attributes like effective tillers, grains ear $^{-1}$ and 1000 grain weight were reduced under delayed sowing which may be responsible for lesser grain yield. Similar results have been reported by Qasim et al., (2008), Gao et al., (2014) and Andarzian et al., (2015).

The grain yield varied with the nitrogen treatment imposed. The highest grain yield of $44.75 \mathrm{q} \mathrm{ha}^{-1}$ straw yield (86.83 $\left.\mathrm{q} \mathrm{ha}^{-1}\right)$ and biological yield (131.59 q ha ${ }^{-1}$ ) was obtained when nitrogen was applied at $150 \mathrm{~kg} \mathrm{~N}^{-1}$ $\left(\mathrm{N}_{3}\right)$, which was significantly higher than $\mathrm{N}_{0}$ and $\mathrm{N}_{1}$ but remained statistically at par with $\mathrm{N}_{2}\left(100 \mathrm{~kg} \mathrm{~N} \mathrm{ha}^{-1}\right)$. The lowest grain yield (31.0 q ha ${ }^{-1}$ ), straw yield (61.67 $\mathrm{q} \mathrm{ha}^{-1}$ ) and biological yield $\left(92.67 \mathrm{q} \mathrm{ha}^{-1}\right)$ was recorded in the nitrogen control treatment $\left(\mathrm{N}_{0}\right)$. The lower grain yield in nitrogen deficit treatments may be due to lower soil nitrogen availability to the extent that could limit its extraction by roots and imposing severe physiological limitations like accelerated leaf senescence, 
damage to photosynthetic machinery and shortening of growth cycle, reduced carbon fixation and assimilate translocation or reduced grain set and development (Shahid and Ram, 2016). Moreover, the yield attributes like effective tillers, grains ear ${ }^{-1}$ and test weight were reduced, which were also responsible for reduced grain yields.

Grain yield showed non-significant interaction (Table 5) was found between the sowing dates and nitrogen levels, it was found that $15^{\text {th }}$ October sowing of wheat is most suitable in terms of yield under rainfed conditions of temperate Kashmir. Irrespective of sowing dates, application of $100 \mathrm{Kg} \mathrm{N} \mathrm{ha}^{-1}$ to crop resulted in higher growth, yield attributes and yield of wheat as compared to other nitrogen levels, further increase in $\mathrm{N}$ application beyond $100 \mathrm{Kg} \mathrm{N} \mathrm{ha}{ }^{-1}$ showed non-significant increase.

Harvest index was not significantly influenced by the date of sowing and irrigation schedule.

\section{Quality parameters}

Data on grain protein and gluten content (Table 4) revealed that $15^{\text {th }}$ November being at par with $30^{\text {th }}$ October recorded significantly higher grain protein than $15^{\text {th }}$ October. Low grain protein content due to early sowing date $\left(15^{\text {th }}\right.$ October) might be attributed to higher yield, consequently dilution effect. Sharma (1997) also observed significantly lower protein content with early sowing.

Increasing nitrogen levels resulted in significant increase in grain protein and gluten content upto $100 \mathrm{~kg} \mathrm{~N} \mathrm{ha}{ }^{-1}$, further, increase resulted in non-significant results. Variation in protein and gluten content between different nitrogen levels have been reported by was reported by Shahid and Ram (2017).
On the basis of generalization of the results obtained, it was found that $15^{\text {th }}$ October sowing of wheat is most suitable in terms of yield under rainfed conditions of temperate Kashmir. Irrespective of sowing dates, application of $100 \mathrm{Kg} \mathrm{N} \mathrm{ha}^{-1}$ to crop resulted in higher growth, yield attributes and yield of wheat as compared to other nitrogen levels, further increase in $\mathrm{N}$ application beyond 100 $\mathrm{Kg} \mathrm{N}$ ha $^{-1}$ showed non-significant increase. Late sowing and no application of nitrogen recorded lowest yield of wheat crop.

\section{References}

Alam, P., Kumar, S., Ali, N., Manjhi, R. P., Kumari, N., Lakra, R. K. and Izhar, T. (2013. Performance of wheat varieties under different sowing dates in Jharkhand. J Wheat Res 5: 61-64.

Andarzian, B., Hoogenboom, G., Bannayan, M., Shiralid, M., and Andarzian, B. 2015. Determining optimum sowing date of wheat using CSM-CERESWheat model. Journal of the Saudi Society of Agricultural Sciences 14: 189-199.

Angadi, S.A. and Janawade, A.D. 2001. Grain and yield attributes of Dicoccum wheat as influenced by irrigation schedules and sowing dates in vertisols. Karnataka Journal of Agricultural Sciences 14(3): 578-581.

Balasubramanian, V., Adhya, T. K., Ladha, J. K. 2012.) Enhancing eco-efficiency in the intensive cereal-based systems of the Indo-Gangetic Plains. In: Issues in Tropical Agriculture Eco efficiency From Vision to Reality. CIAT Publication, Cali, CO.

Bannayan, M., Eyshi, Rezaei, E. and Hoogenboom, G. 2013. Determining optimum sowing dates for rainfed wheat using the precipitation uncertainty model and adjusted crop 
evapotranspiration. Agric Water Manage 126:56-63.

Bassu, S., Asseng, A., Motzo, R. and Giunta, F. 2009. Optimizing sowing date of durum wheat in a variable Mediterranean environment. Field Crops Res 111:109-118.

Deshmukh, K. M., Nayak, S. K., Damdar, Rupali and Wanjiri, S. S. 2015. Response of different wheat genotypes to different sowing time in relation to GDD accumulation. Adv Res J Crop Improv 6:66-72.

Gao, Y., Yang, L., Shen, X., Li, X., Sun, J., Duan, A. and $\mathrm{Wu}, \mathrm{L}$. 2014. Winter wheat with subsurface drip irrigation (SDI): Crop coefficients, water-use estimates, and effects of SDI on grain yield and water use efficiency. Agric Water Manage 146:1-10.

Ghadekar, S.R., Khattar, K.D., Chipde, D.L. and Das, S.N. 1992. Studies on the growth, development, yield and photothermal unit requirement of wheat under different weather conditions in Nagpur region. Indian Journal of Agricultural Research 26(4):195-204.

GoI, 2014. Agricultural statistics at a glance. Ministry of Agriculture, Department of Agriculture and cooperation, Directorate of Economics and Statistics, Government of India, pp. 68-69.growth and yield of wheat (Triticum aestivum L.) as affected by manganese application. Pak J Bot 43:607-616.

Gul, M. K., Egesel, C.O., and Turhan, H., 2008. The effects of planting time on fatty acids and tocopherols in chickpea. European Food Research and Technology. 226:517-522.

Iftikhar, M. H., Shamshad, H. S., Hussain, S. and Iqbal, K. 2002. Growth, yield and quality response of three wheat (Triticum aestivum L.) varieties to different levels of $\mathrm{N}, \mathrm{P}$ and $\mathrm{K}$. International journal of Agricultural biology. 4: 362-364.Jackson M L (1967)

Soil Chemical Analysis. Pp: 234-46 Prentice Hall of India, Private Limited, New Delhi.

Jackson, M. L. 1973. Soil Chemical Analysis. Pp: 234-46 Prentice Hall of India, Private Limited, New Dehli.

Jat, L. K., Singh, S. K., Latare, A. M., Singh, R. S. and Patel, C. B. 2013. Effect of dates of sowing and fertilizer on growth and yield of wheat (Triticum aestivum) in an Inceptisol of Varanasi. Indian $J$ Agron 58:611-614.

Kour, M., Singh, K.N., Thakur, N.P., and Sharma, R. 2012. Crop performance, nutrient uptake, nitrogen use efficiency and harvest index pf wheat (Triticum aestivum) genotypes as influenced by different sowing dates under temperate Kashmir and its validation using CERES model. Indian Journal of Agricultural Research 46 (2):19-126.

Lemaire, G., Jeuffroy, M.H., and Gastal, F. 2008. Diagnosis tool for plant and crop $\mathrm{N}$ status in vegetative stage: Theory and practices for crop $\mathrm{N}$ management. European Journal of Agronomy 28: 614-624.

Mamo, M., Malzer, G.L., Mulla, D.J., Huggins, D.R., and Strock, J. 2003. Spatial and temporal variation in economically optimum nitrogen rate for corn. Agronomy Journal 95: 958-964.

Mumtaz, M. Z., Aslam, M., Nasrullah, H. M., Akhtar, M. and Ali, B. 2015. Effect of various sowing dates on growth, yield and yield components of different wheat varieties. American-Eurasian J Agric Env Sci 15:2230-2234.

Olsen, S. R., Cole, C. V., Waternade, F. S. and Dean, L. A. 1954. Estimation of available phosphorus in soil by extraction with sodium bicarbonate. USDA Cir 939, 19.

Qasim, M., Qamer, M., Faridullah, and Alam, M. 2008. Sowing dates effect on yield 
and yield components of different wheat varieties. J Agric Res 46:135-140.

Ramesh, P., Singh, M. and Rao, S. A. 2005. Organic farming; its relevance to the Indian context. Current Science 88(4):561-568.

Rinaldi, M. 2004. Water availability at sowing and nitrogen management of durum wheat: a seasonal analysis with the CERES-Wheat model. Field Crops Research. 89:27-37.

Sarwar, N., Maqsood, M., Mubeen, K., Shehzad, M., Bhullar, M. S., Qamar, R., and Akbar, N. 2006. Effect of different levels of irrigation on yield and yield components of wheat cultivars. Pakistan Journal of Agricultural Science. 47: 371-734.

SAS, version 9.4, SAS Institute, Inc., Cary, NC, USA.

Sepaskhah, A.R., Azizian, A., and Tavakoli, A.R., 2006. Optimal applied water and nitrogen for winter wheat under variable seasonal precipitation and planning scenarios for consequent crops in a semi-arid region. Agricultural Water Management. 44:113-122.

Shahid, B. D. and Ram, H. 2016. Grain Yield, Nutrient Uptake and Water-Use Efficiency of Wheat (Triticum aestivum) Under Different Moisture Regimes, Nutrient and Hydrogel Levels.
Indian Journal of Agronomy 61(1):5861

Sharma, M.M. 1997. Influence of sowing dates on wheat (Triticum aestivum L.) varieties. M.Sc thesis submitted to Shere-Kashmir University of Agricultural Sciences \& Technology of Kashmir, pp 95-98.

Singh, S. and Pal, M. 2003. Growth, yield and phenological response of wheat cultivars todelayed sowing. Indian Journal of Plant Physiology 8(3):277286.

Subbiah B V and Asija G L (1956) A rapid procedure for the estimation of available nitrogen in soils. Curr Sci 25: 259-60.

Subedi, K.D., and Ma, B.L. 2009. Assessment of some major yield limiting factors on maize production in a humid temperate environment. Field Crops Research. 110: 21-26.

Tomar, S. P. S., Tomar, S. and Srivastava, S. C. 2014. Yield and yield component response of wheat genotypes to different sowing dates in grid region of Madhya Pradesh. Int J Farm Sci 4: 1-6.

Walkley A, Black T.A. 1934. An examination of the digestion method for determining soil organic matter and a proposed modification of chromic acid titration method. Soil Science 37: 29-38.

\section{How to cite this article:}

Shahid B. Dar, R.H. Kanth, Waseem Raja, S.A. Bangroo and Mir, S.A. 2018. Performance of Wheat in Relation to Sowing Dates and Nitrogen Levels under Rainfed Conditions of Kashmir. Int.J.Curr.Microbiol.App.Sci. 7(04): 2600-2608. doi: https://doi.org/10.20546/ijcmas.2018.704.296 